\title{
Security Agencies and Parliamentary Committees of Inquiry in Germany: Transparency vs. Confidentiality
}

\author{
Sebastian von Münchow *
}

\section{Introduction}

"Good governance" is the political concept through which transitional and post-conflict states seek to be integrated into those parts of the international community that embrace the ideals of democracy and the rule of law and place a premium on the will of the people. One of the most decisive factors for the implementation of good governance is in how the security sector interacts with the state and contributes to the public welfare. In particular, the security sector should be subject to civilian oversight and control, make decisions that are comprehensible, and be held accountable for misconduct and unlawful actions.

This concept has led to a worldwide movement for security sector reform (SSR). As the global SSR agenda has been developed and implemented over the past decade, there has been increasing pressure to better integrate the security sector into the state in an effort to restrict the use of security forces as oppressive tools for power by a particular regime, clan, or individual. This is the most important task facing those countries that are embarking on SSR processes in an effort to align themselves more closely with the Euro-Atlantic security space, as the most crucial element in reforming a security sector is to build a nationally-owned and led vision of security that embraces modern-day standards of transparency.

In this light, several states in the Caucasus, Southern Europe, and the Middle East have launched reform initiatives to strengthen parliamentary control and governmental oversight over police services, the military, and intelligence services. There are numerous examples where previous security sectors of states within those and other regions have been involved in serious human rights abuses and have colluded in maintaining a corrupt or tyrannical regime. Considering this sometimes difficult background, it becomes even more obvious what a huge effort a reform seeking transparency in the secu-

\footnotetext{
Dr. Sebastian von Münchow is a lecturer of security studies and international/European law at the George C. Marshall European Center for Security Studies. He studied law at the Free University of Berlin, the Université de Lausanne and the Christian-Albrechts-University Kiel. After receiving the Masters of Law, he took the Berlin bar exam and earned his doctorate in international relations from the University of Vienna on multilateral engagements in post conflict peace-building. Dr. von Münchow then worked for the field missions of the Organization for Security and Co-operation in Europe in Bosnia and Herzegovina, as well as in Kosovo. He has also served in the Police Assistance Mission of the European Union in Tirana. In Brussels, he joined the Office of the Special Coordinator of the Stability Pact for South Eastern Europe where he headed several initiatives to strengthen the home and justice sectors in the Balkans. After returning to Germany, Dr. von Münchow became government official and worked for several years in the Federal Chancellery.
} 
rity sector actually entails. Visible indications of the implementation of good governance are vague at best with respect to both internal and external security, making them particularly difficult to identify. However, if parliamentary control and closer supervision by the ministries of the civilian government lead to the exposure of serious deficits within the power apparatus of the state-especially in the sensitive field of intelligence services - and succeed in drawing reasonable conclusions without reverting to historic behavioral patterns, then this would be counted as a strong indication of progress. The Federal Republic of Germany has spent decades reforming their security sector, and can serve as an example that other states might follow.

Over the last few decades the Federal Republic of Germany has developed a complex system of checks and balances to provide oversight within the security sector. Some of the checks and balances that have been put into place within the many layers of the security sector to ensure there is sufficient oversight are:

- Distinctions between the fields of responsibility for federal and state agencies

- An emphasis on the different aspects of oversight in the form of parliamentary control and executive supervision of the security sector

- A consistent judicial system, along with institutions such as the permanent Parliamentary Control Panel

- Investigations into and the publication by the media of misconduct and unlawful actions.

Similarly, other Western-oriented states have created diverse mechanisms for control and oversight of their security sectors, wherein the scope, means of intervention, and composition of responsible authorities vary. More often than not, the balancing act between the executive and legislative branches has led to the establishment of expert or parliamentary institutions dedicated to questions of budget, lawfulness of actions, and strategic alignment of the intelligence services.

Unique to Germany are the ad hoc parliamentary Committees of Inquiry (COI) at the federal level. In the past, these special-purpose committees focused on security issues and how German authorities dealt with them. Certain tensions naturally arose between the legislative and executive branches of the government. The parliamentary side invoked the general public's interest to clarify the respective circumstances and demanded that the inquiries be appropriately rigorous. For their part, the security agencies sometimes hesitated to disclose sensitive information. And this is exactly where the distinction from other models of oversight and control lies. In contrast to many other permanent oversight and control institutions, the members of a parliamentary COI in Germany enjoy largely unrestricted access to classified material, and benefit from the witnesses' duty to appear at the hearings, as well as from the possibility of public denunciation of any misconduct or illegal actions on the part of the security and intelligence services. The intensive investigative methods that are at the disposal of the members of the COI during an inquiry - which is always seeking a balance between the need for confidentiality and the right to inform the public_-is what makes the German approach interesting 
for those states that are looking for models of how to exercise better control over their security sector, including the intelligence services.

By referring to specific cases, I wish to outline the nature of the German committees of inquiry. The task of balancing confidentiality and transparency will become obvious in the elaboration of legal matters and the presentation of the actual methods and practices utilized by the government. The article closes with considerations of whether the German COI can serve as a model for states in a transitional phase.

\section{A Look at Previous COIs}

Looking at the situation in Germany over the past twenty years, one can see that every legislative term has seen at least one incident in connection with foreign and security policy that led to an inquiry at the federal level that lasted several years and whose discussion elicited considerable emotion. ${ }^{1}$ These committees were repeatedly under close scrutiny by the media, and some of them generated significant public outcry, leading to some ministers or senior administrators being disciplined or even resigning from their posts. The political parties involved in the inquiries position themselves according to a recurring pattern: while the opposition interprets the facts of a case as scandalous, the respective government coalition being scrutinized tries to comment on the proceedings as little as possible or appease their political opponents.

During the twelfth legislative term, the role of the former head of the Department for Commercial Coordination in former Eastern Germany, Alexander Schalck-Golodkowski, was subjected to inquiry. ${ }^{2}$ Only one year later, during the thirteenth legislative term, from 1995-98, the Federal Intelligence Service (BND) had to justify its actions in connection with the so-called "plutonium scandal." ${ }^{3}$ Foreign policy was at the center of

1 This approach contrasts with investigations in the German federal states, which tend to concentrate on the use of public funds - usually in controversial large-scale construction projects. See, for example, Stuttgart 21, "Recommended Decision and Report of the Committee for Transport, Construction and Urban Development,” BT-D print17/5172 (22 March 2011); and "Assessment Report of the Parliamentary Committee of Inquiry: Elbe Philharmonic Hall, Citizens of the Free and Hanseatic City of Hamburg," print 19/8400 (21 January 2011), 5.

2 See the "Recommended Decision and Supplementary Report of the First Committee of Inquiry: Scrutiny of the role played by the 'Commercial Coordination' department and its head Alexander Schalck-Golodkowski in the SED leadership, state control and the economy of the GDR, and findings on who benefited or benefits to this day from the economic activities of this department," Bundestag print 12/8595 (2 November 1994), 39.

3 See "Recommended Decision and Report of the First Committee of Inquiry: Findings on the Munich Plutonium Incident and issues related to this and other incidents, with a focus on the responsibility of the federal government and the personnel of federal agencies" ("Plutonium COI"), Bundestag print 13/10800 (28 May 2008), 45. 
attention in the so-called "visa affair" during the fifteenth legislative term, ${ }^{4}$ and the following term then saw what is probably the most substantial parliamentary inquiry to date into the work of German security agencies. The COI put several individual cases under scrutiny, such as those of Khaled El-Masri, Mohammed Zammar, and Murat Kurnaz, who were each temporarily apprehended overseas in connection with the U.S.-led war against terrorism, German activities in Baghdad during the third Gulf War, and the oversight and surveillance of journalists by the security sector under the pretenses of force protection and operation security. ${ }^{5}$ During the seventeenth legislative term, the Defense Committee came together as a COI and questioned the legitimacy of a German air strike against two gas trucks in Kunduz, Afghanistan, in September 2009. ${ }^{6}$ Starting in 2012, another committee was set up to investigate a neo-Nazi gang, the so-called "Zwickau Cell," whose crimes had gone undetected for years. ${ }^{7}$

In contrast to this are those security-related issues that were discussed in public but never made it to the COI level. In this context, the German Minister of Defense at the time and the Coordinator for Intelligence Services in the German Chancellery resigned from their posts in the early 1990s following discrepancies related to the export of weapons from the former East Germany. ${ }^{8}$ Another case that was never investigated in a committee was that of a journalist whose private e-mail traffic had been unintentionally intercepted by the German intelligence service BND in $2008 .^{9}$ It was handled by the Par-

4 See "Recommended Decision and Report of the Second Committee of Inquiry: Findings on whether members of the federal government or other government officials have in any way compromised or endangered the security of the Federal Republic of Germany or of other Schengen countries as of October 1998 when implementing immigration law through decrees, instructions or otherwise, in particular through the issuance of visa at German diplomatic missions, in particular in Moscow, Kiev, Tirana and Pristina" ("Visa COI"), Bundestag print 15/5975 (2 September 2005), 285.

5 See "Recommended Decision and Report of the First COI: Open questions concerning incidents in relation to the war in Iraq and the fight against international terrorism" ("First COI of the Sixteenth Election Period"), Bundestag print 16/13400 (18 June 2009), 353-418.

6 See "Recommended Decision and Report of the Defense Committee of the First COI: Inquiry into the command issued by the military leader of the provincial reconstruction team (PRT) in Kunduz/Afghanistan to carry out an air strike against two gas trucks on 3 and 4 September 2009 , into the reconnaissance and information policy of the federal government, as well as into the compatibility of the chosen courses of action with national and multinational political, legal and military guidelines for the mission in Afghanistan" ("Kunduz COI"), Bundestag print 17/7400 (25 October 2011), 29, 169.

7 See "Request to Set up a Committee of Inquiry," Bundestag print 17/8453 (24 January 2012).

8 See "Reply by the Federal Government: Procurement of weapons from the East by the Federal Intelligence Service and transit shipment to friendly states," Bundestag print 12/2513 (30 April 1992).

9 See "First COI of the Sixteenth Election Period," 474. 
liamentary Control Panel, a permanent body that oversees the work of the intelligence services at the federal level. ${ }^{10}$

\section{Preliminary Stages of a Committee}

In the past, security policy issues that eventually became the subject of a parliamentary inquiry were usually not the focus of discussion within the political arena or the media until shortly before or after federal elections. The reason for this is, on the one hand, the uncertain outcomes of the election campaign itself and, on the other hand, the potential party coalitions of both the government and opposition that would take shape after the elections. The experience of how intensely the public follows this kind of inquiry may serve as an inspiration to any opposition party to find a topic with the potential to bind a government for years to come.

To mention only one example, in late 2005 and early 2006, the new federal government tried to thwart the creation of a COI by publishing a report aimed at countering the allegations in the media and the increasing number of critical questions regarding the war on terror in the regular Bundestag (the lower house of parliament) committees. ${ }^{11}$ The attempt failed. In a scope probably unparalleled anywhere in the world, the security agencies had gathered material to rebut the criticism. But the opposition parties still had "open questions," and it was decided that a committee should be set up. ${ }^{12}$ One conse-

10 The Parliamentary Control Panel is responsible for the oversight of federal intelligence agencies. The federal government is obliged to inform the committee in detail about the activities of the intelligence services. Its consultations are subject to strict confidentiality and non-disclosure - see http://www.bundestag.de/bundestag/gremien/pkgr/index.jsp and Dietmar Peitsch and Christina Polzin, "Die parlamentarische Kontrolle der Nachrichtendienste" ["Parliamentary Control of the Intelligence Services"], Neue Zeitschrift für Verwaltungsrecht (2000): 38793. It is worth mentioning that most states do not have any independent parliamentary oversight of their intelligence services, but merely oversight structures in the responsible ministries. See Hans Born, "Towards Effective Democratic Oversight of Intelligence Services: Lessons Learned from Comparing National Practices," Connections 3:4 (2004): 1-12. See also Jelle van Buuren, Secret Truth: The EU Joint Situation Centre (Amsterdam: Eurowatch, 2009).

11 See Dana Priest, "CIA Holds Terror Suspects in Secret Prisons," Washington Post (2 November 2005); available at http://www.washingtonpost.com/wp-dyn/content/article/2005/11/01/ AR2005110101644.html. The federal government presented a final report "On the incidents in relation to the war in Iraq and the fight against international terrorism" to the Parliamentary Control Panel on 20 February 2006. To further investigate any remaining issues, and to determine assessments and possible consequences, a committee of inquiry was set up according to Article 44 of the Basic Law.

12 See "The Green Party, the Liberals and the Left Party Decide to Set up a COI to Inquire into the BND Scandal," Der Spiegel online (17 January 2006); available at www.spiegel.de/politik/ deutschland/bundestag-gruene-fdp-und-linkspartei-beschliessen-untersuchungsausschuss-zurbnd-affaere-a-395748.html. See Also "BND-Ausschuss," Die Zeit online (12 April 2006); available at www.zeit.de/online/2006/15/BND. 
quence, among others, was that confidential information was made public even before the COI had begun its work.

Setting up a COI at the federal level usually means that dozens, if not hundreds, of employees of the affected government agencies as well as the parliament's administration are tied up for several years. Huge amounts of original and copied files are moved and a large number of witnesses are brought to Berlin for hearings, some of them from far-away regions.

\section{The Setting-up of a COI and its Relevance in Terms of Constitutional Law}

A motion to set up a COI in the Bundestag can be proposed by a quarter of the members of the parliament - the so-called "qualified minority" - in accordance with Article 44, Paragraph 1, Section 1 of Germany's Basic Law. This makes it clear that an inquiry into misconduct and illegal actions is almost always possible, and cannot be rejected by a majority vote in the Bundestag. Thus, the right to have an inquiry is one of the most significant democratic rights in Germany. Parliamentary COIs are enshrined in the Basic Law and are part of those legal provisions guaranteeing the minority the greatest power to pursue their political agendas within the coalition-opposition arrangement. ${ }^{13}$

The decision to set up a committee must be made in accordance with the Constitutional Law. This means that the ability to limit the scope of the inquiry by means of interpretation must be adequately defined. ${ }^{14}$ The Bundestag determines how many and which of its members will be part of the committee. The number mirrors the size of the various party groups making up that particular legislature. As a rule, either seven or eleven deputies respectively will form the committee. The chairman of the committee is a member of the strongest faction, and his or her deputy a member of the second strongest faction. ${ }^{15}$ Generally, the sessions take place during the sitting weeks of the parliament. Special sessions can be convened, but must be approved by the President of the Bundestag. $^{16}$

If the facts of the matter align with the portfolio of the Ministry of Defense, the Defense Committee will be responsible to constitute itself as a COI. ${ }^{17}$ This occurred during

13 See Reinhard Bergmann in Grundgesetz für die Bundesrepublik Deutschland-Taschenkommentar [Basic Law for the Federal Republic of Germany-Pocket Commentary], $7^{\text {th }}$ ed., ed. Karl-Heinz Seifert and Dieter Hömig (Berlin: Nomos, 2003), 369.

14 The decision to set up a committee of inquiry becomes effective if the subject of the inquiry is adequately defined. See Constitutional Court of Saxony, 154-I-07 (29 August 2008), 29; Decisions made by the Federal Constitutional Court 124, 78 [117]; State Court of Hesse, Decisions by the Administrative Court 17, 1 [17]; 22, 136 [140]; State Constitutional Court of Saxony-Anhalt, Decisions by the State Constitutional Court 15, 353 [358].

15 See Sections 4-7 of the Committee of Inquiry Act.

16 See Section 8, Committee of Inquiry Act.

17 See Section 34, Paragraph 4 of the Committee of Inquiry Act; according to Article 45(a), Paragraph 3 of the Basic Law, no committee of inquiry can be set up for defense issues, nor can the Defense Committee be given an inquiry mandate. 
the seventeenth legislative term to investigate the events surrounding the air strike in Kunduz, Afghanistan, in September 2009.

\section{The Rights of the COI and of the Executive Branch}

The rights of the COI are stipulated in the German Bundestag's Committees of Inquiry Act with reference to sections of the Code of Criminal Procedure. ${ }^{18}$ This means that the COI's procedure is similar to that in criminal proceedings, especially with regard to the legitimacy of material evidence and witness testimony. Yet the committee is not a court of law. In the end, it merely compiles a report that is submitted to the President of the parliament. ${ }^{19}$

The factions can make motions to hear evidence in the COI. Only one-fourth of the votes of the committee members are needed for this. The COI hardly ever rejects such a motion, as it would risk being accused of obstructing the parliament's (and therefore the public's) access to information. But it is possible according to the law. Inadmissibility can be claimed if the motion to hear evidence is improper - for example, if it is intended to delay proceedings - or asks to inquire into a topic that is not covered by the COI's mandate. ${ }^{20}$

The federal government, on the other hand, has an obligation to support the COI in its mission to clarify the facts. This obligation for cooperation follows the principle that governmental officials must act in accordance with their respective constitutional duties, a principle that all constitutional bodies must adhere to. On a day-to-day basis this means, for instance, that no documents can be withheld from the COI, even if sharing them would be politically inconvenient. Witnesses related to the executive branch must tell the truth before the committee even when it conflicts with their political and positional interests.

The federal government has the right to dispatch representatives from all departments affected by the mandate who, in accordance with Article 43, Paragraph 2 of the Basic Law, are entitled to attend and to speak at committee sessions. However, the representatives may not direct questions to the witnesses called by the committee. They normally appoint a person to represent the government's position. This appointed representative has the right to ask the chairperson if the questions asked by the members of

18 According to Section 36 of the Committee of Inquiry Act, there is the possibility to appeal to an investigating judge at the Federal Court of Justice. This was done during the work of the committee of inquiry in the sixteenth legislative term, overruling objections by the opposition. See "First COI of the Sixteenth EP," 48.

19 The work of a COI can, however, lead to criminal proceedings. Witnesses have to tell the truth. If not, they can be sued for making false statements while not under oath, cf. $\S 153$ Criminal Code. See also "Plutonium COI," 25.

20 See Sections 10 and 17 of the Committee of Inquiry Act; and Bergmann in Grundgesetz für die Bundesrepublik Deutschland-Taschenkommentar, ed. Karl-Heinz Seifert and Dieter Hömig, Art. 44, Para. 2 (1), margin no. 6. Requests to present evidence make it possible to determine at an early stage which kind of evidence the deputies plan to use with regard to a subject. 
the Bundestag perhaps go beyond the scope of the inquiry, or exceed or violate the right to take evidence. His function is similar to that of an authorized proxy at court.

\section{Mandate for a COI}

Any conceivable mandate for a COI basically follows the same pattern:

- Who did what, when, how, with whom, with what, and why?

- Was this lawful and/or politically appropriate?

- Which internal and/or political decision makers knew about it and bear responsibility?

- What are the lessons learned?

The last question is relevant only for the representatives of the Bundestag who can make suggestions for future action in their final report. However, the preceding questions are necessary for the legislative body to obtain the relevant information from the executive agencies. Generally, the mandate for a COI can be interpreted verbatim. The mandate dictates which facts will need to be investigated and where the political debates can be expected to run parallel to the inquiry. ${ }^{21}$ The time period to be investigated begins at the initial point in time when the circumstances of interest took place. The end point is the day when the COI was set up. Currently pending actions may not be challenged, as this would undermine the prohibition of collateral control. ${ }^{22}$

The upper echelons of the departments involved in the COI make the fundamental decision of whether a mandate is to be interpreted in a broad or a narrow fashion. In the end, it is their decision whether to allow for greater transparency. A broad interpretation will lead to the presentation of a large number of files, and will require the witnesses to answer a wide range of questions. On the other hand, the consequences of a narrow interpretation might mean that only a small number of files will be considered relevant, and that witnesses may only be asked to answer narrowly defined factual questions. ${ }^{23}$

${ }^{21}$ In this context, certain phrases and terms may seem somewhat vague and create uncertainty. Therefore it is recommended to consult the decision recommendations, the minutes of the plenary debate, and/or statements made by individual deputies. See Decisions by the Federal Constitutional Court 124, 78 [118 f.]

22 See Decisions by the Bavarian Constitutional Court 38, 165 [177]; Böckenförde, Parliamentary Committees of Inquiry and Local Autonomy, 1 f.; Achterberg/Schulte Kommentar zum Grundgesetz [Commentary on the German Basic Law], Vol. 2, $4^{\text {th }}$ ed., ed. Hermann von Mangoldt, Friedrich Klein, and Christian Starck (Munich: Vahlen, 2000), Art. 44, margin no. 61.

23 These basic guidelines may, however, be open to interpretation for practical purposes. While during the "First COI of the Sixteenth EP" Parliament was told quite clearly that, due to the nature of the cause, the government could only grant a limited degree of transparency, it received full, unconditional, and generous support during the investigations of the Kunduz committee. 


\section{Evidence}

Orders from the committee to obtain evidence must be adequately defined and must serve the aim of gathering information. However, it is acceptable for the order to be vague to a certain degree. It is generally assumed that a line is crossed if the evidence orders resemble "a shot in the dark." It is important for the institutions of the executive branch that these orders use evidence that supports the mission of the COI. This means that these orders are like stencils that, if superimposed on the COI's mission, outline specific aspects for which they demand material evidence or witness testimony.

For example, consider an evidence order the COI submits at the beginning of its work, or whenever it calls a new case complex. When the committee members pursue a line of questioning concerning "who at what point in time, knew what, from whom, about available intelligence, motives, execution, and the consequences of the air strike," the corresponding order will usually request all files, documents, correspondence, etc., available from all agencies that are potentially involved. This simple example serves to demonstrate that all affected parts of the security sector, if possible, will try to gather all relevant documents and records available and connected to the COI's mission to bring before the parliament for clarification. ${ }^{24}$

But the key question is what is considered relevant, and therefore requires the authorities to bring the material before the parliament? This differentiation is vital not only in a legal, but also in a practical sense. Information that is not relevant is not part of the inquiry, and therefore need not be presented to the committee. It is illegal for parliament to conduct an inquiry that is too generalized. For example, it would have meant an abuse of authority if in the context of the investigation into the Kunduz air strike the committee had asked the Ministry of Defense and the German Armed Forces to turn over all documents ever produced regarding Afghanistan.

The question of who determines what information is relevant to a COI's mission was a contested constitutional issue during the sixteenth legislative term, and was brought before the Constitutional Court. ${ }^{25}$ The Federal Constitutional Court ruled in July 2009 that the federal government's interpretation of relevance had violated the rights of the COI. The Constitutional Court did not grant the executive branch the discretion to decide which documents contain relevant information for the Bundestag and which ones do not. However, due to the realities of actual possession of the information, the executive branch continued to assume a de facto right of interpretation. It does so in light of the Bundestag's duty to clearly define the mandate of the COI. In the end, an unspoken compromise seemed to be in the best interest of both sides. In most cases, this is the obvious solution. For example, it cannot be beneficial to the inquiry to request information

24 Things tend to get more complicated when the committee makes the decision to obtain evidence during the course of the investigation. It may happen that witnesses make statements about lines of action that had not been considered relevant before, or had simply been unknown. Usually the committee is interested in such surprise twists, which makes it necessary to request evidence that may lead to new findings. 
on all activities in the Balkans if the only relevant aspect is the question of who knew what and when about the apprehension of a suspected terrorist in Bosnia-Herzegovina.

The Constitutional Court did not answer the question of whether the COI may request complete insight into existing files. After all, committee members theoretically know the file numbers from the documents that have been brought before them, but none has ever requested a complete file. One possible explanation might be that the members of the Bundestag are concerned that they will be overwhelmed by files and documents. The service provided by the government agencies to pre-select the relevant files seems more productive. Insisting on having full insight into all the events would indeed be less useful, as this would lead to the authorities being obliged to print out all press releases referring to the discussed topic. The number of files would increase dramatically.

But yet again, the decision of the Constitutional Court strengthened the parliament's interest in the disclosure of relevant files. It also ruled that it was not within the scope of the executive's authority to make the sole determination for or against transparency where sensitive information is concerned.

\section{The Executive's Right to Withhold Documents}

The question of whether there is evidence that can be withheld from the committee on legal grounds is another contributing factor to the tension in the effort to find a balance between disclosing and withholding information. The limits on the right to obtain evidence were also controversially discussed during the sixteenth legislative term. This played a role during the aforementioned case ruled on by the Federal Constitutional Court. On several previous occasions, the Constitutional Courts had determined the circumstances under which a government may refer to its right to withhold files from a parliamentary investigation. But for the complex inquiries of the committee during the sixteenth legislative term, only vague guidelines had been established by previous court decisions. The opposition seized the opportunity and used some rejected files, calling upon the Federal Constitutional Court to make a ruling on the scope of the parliament's right to conduct inquiries with regard to the limitations of the right to evidence. ${ }^{26}$ They also attacked the narrow limitations imposed on witnesses who have been authorized to testify by the government's agencies. This was another occasion where the Constitutional Court strengthened the Bundestag's right to acquire information at the expense of the federal government's interests. On the other hand, the Constitutional Court also determined that the limitations on parliament's rights referred to by the federal government were not unlawful per se.

As a consequence, the government side rephrased their permissions to testify and the requirements for substantiation in order to comply with the court's ruling. Transparency was made paramount in those cases in which the committee would be denied access to documents. However, access to parts of or whole documents can be denied to parliament for the following reasons: for Staatswohl (national interest); the core areas of executive

26 Decisions by the Federal Constitutional Court 67, 100 [142]; 76, 363 [387]; 77, 1 [46 f.] and "First COI of the Sixteenth EP," 48, 419, 478. 
responsibility; basic civil and human rights; and the lack of original ownership over a piece of shared information. ${ }^{27}$

The Constitutional Court did not question the refusal to share evidence for reasons of the national interest per se, but they also chose not to provide any further clarification either. ${ }^{28}$ It is assumed in this context that evidence could be kept from the committeeand thus eventually from the public - if it would reveal facts that could threaten the national interest or the vital interests of one of the sixteen federal states. That kind of threat is to be assumed if the publication of the documents would affect the continued existence or functioning of the state, threaten its internal or external security, or result in massive disturbances of public security and order. However, the court explained that this kind of threat could not be assumed if the publication would merely inconvenience the government. Furthermore, it pointed out that Staatswohl is entrusted in equal parts to the government and the Bundestag, and that the protection of sensitive information could be achieved through classification. ${ }^{29}$ This reasoning held that the Bundestag, too, must respect the security, protection, and handling of information according to its classification. However, the ruling of July 2009 did not take into account the many press reports that were based on leaked documents.

However, withholding information to protect the national interest will remain the exception to the rule. In those cases, the government must carefully weigh the pros and cons of withholding evidence, and must carefully explain the decision in writing. Over the last few years, subcategories of Staatswohl have also formed, causing the authorities to remain reluctant to release certain documents. This is mainly the case where the core areas of the executive's responsibility and the protection of diplomatic negotiation processes are concerned, and in particular protection of the methods of the intelligence services. This point is of the utmost importance for the intelligence services due to their natural desire to keep their methods covert.

The core areas of the executive's responsibility include which initiatives, consultations, and actions are possible. As a rule, these are not accessible to a parliamentary COI. ${ }^{30}$ Generally, the government should not be under constant supervision, and its members should be able to openly prepare and make decisions without the opposition's interference. This protection has been guaranteed by the assumption of an inaccessible "arcane sphere" of executive responsibility. This particularly refers to cabinet discussions and the preparation of cabinet and department decisions. There was no question of

27 See "First COI of the Sixteenth EP," 24: "Number of files presented."

28 Decisions by the Federal Constitutional Court 67, 100 [134] and Decisions by the Federal Constitutional Court 124, 78 [123].

29 The Federal Constitutional Court had previously argued that it was admissible to apply the guidelines for classification to private secrets as well. See Decisions by the Federal Constitutional Court 67, 100 [135] and $\S 1$, Rules of Procedure of the Bundestag.

30 Decisions by the Federal Constitutional Court 67, 100 [133 f., 139 f.]; 110, 199 [214]; 124, 78 [120]; cf:: Volker Busse, "Der Kernbereich exekutiver Eigenverantwortung im Spannungsfeld der staatlichen Gewalten" ["The Core of Executive Autonomy among Conflicting Priorities of State Powers"], in Die öffentliche Verwaltung 42 (1989): 45. 
the legitimacy of these assumptions; there were discussions, however, about what kind of evidence might fall into that category. Considering the clarifications by the Constitutional Court and the experience from previous committees, it is safe to say that the core area protects evidence that shows proximity to decision making and to issues that have not yet been resolved. ${ }^{31}$ But determining exactly how to make these kinds of classification is difficult. As a general rule, it is to be assumed that a dossier is closed as soon as the government's decision-making process has reached maturity or the internal opinion making is finalized and results are ready to be released for external view. While it is possible, for example, to view the existence of a formal closing directive as the closure of a dossier, uncertainties in other fields remain. Many individual dossiers in connection with the global war on terror, for example, will not be closed in the foreseeable future. In this respect, the executive could persist in its viewpoint that parliament's interest in an investigation affects current dossiers. As a matter of fact, the following question would need to be answered in this respect: Would the disclosure affect the executive's decision making with regard to its current and future functionality as well as its discretion? In some cases, does the interest in maintaining confidentiality outweigh parliament's interest in investigating? Positive answers in both cases would have to be thoroughly justified. Parliament's interest in the investigation usually has more weight in scenarios where obvious breaches of the law are to be investigated. It is precisely in cases related to issues of foreign and security policy that the parliament will be able to refer to this reasoning.

The Constitutional Court ruled that withholding materials produced in preparation for Bundestag sessions or talks with representatives of foreign states was not permissible. ${ }^{32}$ They criticized the government's letters of rejection for not being concrete enough, and held that a weighing of interests had not taken place. Hence, the Constitutional Court once again ruled in favor of transparency over the executive's arguments for discretion.

Third, the government referred to possible violations of fundamental civil and human rights that may be the consequence of a complete and open submission practice for files. ${ }^{33}$ In particular, this applies to the fundamental rights to life and limb of intelligence

31 This is applicable to the minutes of the federal cabinet, to cabinet notations, and submissions to facilitate the decision-making process, as long as no political decision has been made on the current dossier. See Decisions by the Federal Constitutional Court 124, 78 [122 f., 129 f.]

32 See Decisions by the Federal Constitutional Court 124, 78 [170 ff.] on the "First COI of the Sixteenth EP."

33 In the security services, this right to request the taking of evidence may be connected to the basic right to life and bodily integrity, to general personal rights, and to the right to informational self-determination. See Decisions by the Federal Constitutional Court 67,100 [144]. See also Dieter Hömig, in Grundgesetz für die Bundesrepublik DeutschlandTaschenkommentar, $7^{\text {th }}$ ed., ed. Karl-Heinz Seifert and Dieter Hömig, Art. 10, Para. 1, margin no. 1a. 
sources. ${ }^{34}$ It is argued that, following a revelation, the source could face severe punishment or long prison sentences in many states. In this case, too, the result was that parliament's interest in obtaining information must be weighed against a violation of fundamental rights. In cases when the $\mathrm{COI}$ is denied access to information on such grounds, the government must produce substantial justification in a written statement as to the reasons why. ${ }^{35}$

The final, if contested, reason to withhold evidence is the lack of the right of disposal over a written piece of information. This concerns messages that German intelligence services receive from foreign services on the express condition that they must not be disclosed to a third party. ${ }^{36}$ Enforcing this particular legal bar to obtaining evidence is of the utmost importance to all federal and state services, irrespective of the classification level. This would concern all the information received with the explicit statement or implicit assumption that it will be circulated only with the permission of the originator. ${ }^{37}$ There has been a view that the prohibition against passing on this kind of information would nominally fall under the Staatswohl bar. It could be argued that the protection of the so-called "third party rule" ultimately serves the national interest, as the breach of this rule would mean becoming less trustworthy in the eyes of the nation's allies. As a consequence, Germany's international partners would cease to share sensitive information with Germany. This would, in turn, dramatically impair Germany's ability to combat terrorism, for example. ${ }^{38}$

${ }^{34}$ See Hömig, in Grundgesetz für die Bundesrepublik Deutschland-Taschenkommentar, $7^{\text {th }}$ ed., ed. Karl-Heinz Seifert and Dieter Hömig, Art. 10, Para. 2, margin no. 5 f.

35 See Decisions by the Federal Constitutional Court 124, 78 [123 f.], and Decisions by the Federal Constitutional Court 67, 100 [142]. Another matter that needs checking is whether the protection of basic rights can be guaranteed by a categorization according to the General Administrative Provision of the Federal Ministry of the Interior for the physical and organizational protection of classified documents of 31 March 2006.

36 The right to informational self-determination may only be restricted if this is in the interest of the general public and in strict adherence to the principle of proportionality. The restriction may go no further than necessary for the protection of public interests; see Decisions by the Federal Constitutional Court 124, 78 [125].

${ }^{37}$ Information that has been obtained from a third member state or a third country can only be exchanged between the law enforcement authorities of two member states with the consent of that third state. See http://europa.eu/legislation_summaries/justice_freedom_security/police_ customs_cooperation/114581_en.html.

38 The authorization to pass on this type of information has to be specifically requested. In most cases such requests remain unanswered. However, it has happened that partners have either explicitly released the information or maintained the information ban. See Jan Hecker, "Anmerkung zum BVerfG-Beschluss vom 17.06.2009" ["Comment on the Decision of the Federal Constitutional Court of 17 June 2009"], Deutsches Verwaltungsblatt 19 (2009): 1239 ff. See also Decisions by the Federal Constitutional Court 124, 78 [123 f.]. It is also conceivable that lacking power of disposal cannot be categorized as sufficient reason to withhold information. If the authorities cannot dispose freely of the information, they are not open for inspection by the parliament. 
The above proves once again that the Constitutional Court imposes severe restrictions on the government's ability to withhold information for alleged security reasons. However, in the reality of a COI's work, it is to be considered normal that uncertainties regarding the relevance and the limits of the right to take evidence arise and often remain unresolved for several months. A de-escalation can be achieved with the help, for example, of the so-called "chairperson procedure," or the transmission of documents without acknowledging any legal obligation, or the informal discussion of disputed passages. ${ }^{39}$

\section{Compilation of the Files}

On the one hand, the federal government is obliged to provide evidence requested by a $\mathrm{COI}$ as quickly as possible, in a comprehensive fashion. On the other hand, government agencies need a certain amount of time to compile the extensive files containing the documents that are needed to come to a decision. As mentioned above, the files that are to be made available to a COI include all the documents to be found in the official files concerning the dossiers affected by the evidence order. ${ }^{40}$ These can include notes, reports to the leadership, e-mails, letters, press releases with comments, reports, expert reports, etc. Contrary to what outsiders might expect, this means that there are no pre-existing sets of ring binders that only need to be pulled off the shelf and submitted to the Bundestag. Compiling these binders manually might appear trivial at first. However, it is this procedure that explains the immense expenditure of personnel and time. As the whole process of adding dividers, explanatory sheets, pagination, and writing comments regarding classification and reasons for removal is performed by hand, one might imagine the kind of complications to be expected during the process of compiling multi-volume binder sets.

39 In a chairperson procedure, where only the chairperson and the chairperson's deputy have full access to classified material, a small group of deputies may be offered the opportunity to read controversial passages and check whether there is sufficient reason for holding back information. However, the Constitutional Court does not accept this procedure as an alternative to the detailed and substantiated assessment of the pros and cons in cases of the above mentioned bans on the taking of evidence. See Decisions by the Federal Constitutional Court 67, 100 [138f.]; 77, 1 [56]. Another de-escalation mechanism is the ex gratia consignment of documents. It is also used for the hearing of witnesses if it remains unclear whether remarks on facts and circumstances are within or beyond the scope of the inquiry. Of course, the federal government may volunteer evidence not considered relevant or subject to the taking of evidence. However, if such a procedure becomes a matter of routine, it may have a prejudicial effect.

40 A "file" is defined as a collection of documents relating to the same matter which is treated and quoted as a whole, and usually carries a file number. The idea is to have all existing written information on the matter in question available at any time. This meets the written form requirement (documentary character), which is based not only on the existence but also on the availability of documents. A file register ensures the traceability of files. 
This laborious process, along with the need to consult with other affected agencies regarding the content of the files, adds to the time delay. Basically, the departmental principle applies: the different departments compile their respective collections of documents on their own authority. Coordination is required in cases where there has been a previous exchange regarding the facts of the case. Then, hundreds of letters and reply letters, duplicates, and copies must be checked for congruence. There must also be congruence with respect to redacted passages in texts, classification, statements of reasons regarding claims to retain evidence, corresponding documents, and which documents are to be submitted and which ones are not. This might appear rather trivial at first sight, and yet this too is an active effort to get to the bottom of the matter at hand. ${ }^{41}$

One has to bear in mind that the respective departments often consider a multitude of files to be relevant to the facts of the matter. One can imagine the amount of man-hours needed when three or four different ministries and subordinate agencies each wish to align hundreds of pages with the files of the other departments. The past has shown that usually some documents end up being discussed for a rather long time, and often are the cause of significant dispute. In other words, the separate departments connected to the inquiry cannot provide congruent sets of files by simply "having a quick look" into the archives.

So far, there have never been any complaints about differences in style, structure, formatting, etc., between documents. This is not surprising, considering that the documents are studied by people who have never concerned themselves in depth with the events. Ultimately, full and complete congruence between all the different sets of files will never be achieved. The sheer volume of documents and files can easily amount to more than five hundred file binders. A complete alignment of the amorphous contents of files can hardly be achieved. It is difficult to imagine that a ministerial staff member will be able to remember after several months which passages had been blacked out in a document from another department. And this cannot be achieved in a parliamentary environment, either. In addition to that, the administrative practices of the federal govern-

41 See "Committee Finds that Chaos Reigns in the Security Services," at www.bundestag.de/ dokumente/textarchiv/2013/42632406_kw05_pa_2ua_nsu/index.html; "Request for Setting up a COI," Bundestag print 17/8453 (24 January 2012); "Interim Report of the COI 5/1: Possible misconduct of law enforcement and security services of the state of Thuringia, including the responsible ministries and their political leadership, as well as persons cooperating with security services (human sources) in the context of activities of right wing extremist structures, particularly the National Socialist Underground (NSU) and Protection of the Thuringian Homeland (THS) and their members, as well as possible mistakes made by the Thuringia Security Services and Law Enforcement in the investigation and prosecution of crimes committed by the NSU and affiliated networks." This became apparent when the COI was taking the evidence with regard to the murders committed by the terrorist group National Socialist Underground, the so-called "Zwickau Cell." Looking into the misconduct of several authorities was one of the committee's tasks, as well as getting an overview of the records as they stood at the time. Thüringer Landtag, print 5/5810; see also "We Literally Know Nothing, Süddeutsche Zeitung (14 September 2012); available at http://www.sueddeutsche.de/politik/pannen-beinsu-ermittlungen-wir-wissen-buchstaeblich-nichts-1.1467718. 
ment and its departments per se can hardly become the subject of an inquiry. But in order to fulfill the high standards it sets for its administrative work, the government should continue to strive to avoid differences in the records if at all possible.

\section{Testifying as a Witness in the Committee Sessions}

Witness testimony is the second important pillar when inquiring about the facts of a matter. Generally, the COI requests the nomination of witnesses that are to be heard regarding a subject of inquiry via an evidence order. In this context, the security agencies must make sure that those employees are nominated who made relevant observations within the scope of their duties. Otherwise, almost all of the employees would have to be listed, as the debated events are normally known through the media.

According to Section 23 of the Committees of Inquiry Act, in connection with Section 54 of the Code of Criminal Procedure (CoCP), office-holders - that is, every civil servant employed within the German security sector-require permission to give evidence, the scope of which has been disputed before the Constitutional Court. Whereas in the past the permissions to give evidence had been rather narrowly defined, their wording became more abstract from July 2009 on in order to ensure the executive branch's openness with regard to the interest in transparency. ${ }^{42}$ Foreign office holders, as a rule, receive permission to give evidence from their agency, too. So far, most efforts of committees of inquiry to receive permission to hear employees of U.S. agencies in particular have failed. Without going into further detail, the U.S. government has made it clear that it is also not possible to hear former employees as witnesses before the Bundestag. ${ }^{43}$ Persons who have gained knowledge of facts relevant to the case in a different fashion are naturally under no compulsion to give testimony.

From the media's point of view, the testimony of witnesses is the most interesting part of evidence gathering. Bundestag members seize the opportunity to articulate their position in front of the cameras directly before or after the witnesses' testimony. With a two-thirds majority vote and the consent of the witnesses, there is the possibility to broadcast the sessions live on television. ${ }^{44}$

The chairperson opens the hearing of witnesses, and informs the witnesses of their rights and duties. ${ }^{45}$ The time allotted to committee members for speaking or asking questions depends on the size of their faction in parliament. Members of the governing coa-

42 Now witnesses need to quote substantive reasons to explain why in such a case the right to request evidence is limited. For legal experts, that may not be a problem, but it is asking a lot from those who are not familiar with constitutional discourse.

43 See "Kunduz COI," 22: "Hearing of foreign witnesses."

44 See Art. 44, Para. 1 of the Basic Law: "All taking of evidence is public." The Committees of Inquiry Act states that all audio and visual recording is prohibited and that, as a rule, broadcasting is not permitted either. Exceptions, however, are possible, if a two-thirds majority of the members present as well as the person or persons to be heard or to be questioned have agreed. See Decision by the $2^{\text {nd }}$ COI ("Visa Col"), Bundestag print $15 / 5975$ (2 September 2005), 41: "Permission for sound and video recording and film footage."

See $\S 20$, Para. 2, Committees of Inquiry Act. 
lition and the opposition take turns questioning the witnesses. This rotation technique is called "Berlin Hour." ${ }^{46}$ It can be repeated as often as deemed necessary. At the end, the members get the opportunity to ask questions in an open forum.

When witnesses are summoned plays an important and often disputed role in committees of inquiry. In general, the committee tries to follow a certain dramaturgy, i.e. at first, lower-ranking office-holders and other witnesses are heard, with the committee climbing the ladder from department heads up to deputy ministers. ${ }^{47}$ From the media's point of view, the committee hearings culminate with the testimony of the affected ministers, who must justify the actions (or failure to act) of the government regarding the respective matters of inquiry. ${ }^{48}$

The sessions always start out as public sessions, unless they are closed to the public from the outset. This is often the case when employees of the intelligence services are heard. ${ }^{49}$ The exclusion of the public is determined in accordance with Section 14, Para. 1 and 3, and Section 15, Para. 1 and 3 of the COI Act. The reasons stated there do not allow for any discretion. ${ }^{50}$ The classification of the session corresponds to the subject

46 A Berlin Hour is the speaking time in plenary sessions or committees based on the number of seats in Parliament. The current Berlin Hour is sixty minutes, with twenty-three minutes allocated to the SPD and CDU/CSU respectively, nine minutes to the Liberals, and seven minutes each to the Green Party and the Left Party. In case of an overrun, the speaker is admonished by the chairman and then asked to stop. See Hermann Schreiner, "Die Berliner Stunde-Funktionsweise und Erfahrungen: Zur Redeordnung des Deutschen Bundestages" ["The Berlin Hour - How it works: The Rules for Speakers in the German Bundestag"], in Zeitschrift für Parlamentsfragen 36:6 (2005): 573-88.

47 See "Kunduz COI," 18: "The sequence of hearings and recommendations for decisions" and report by the Second COI: "Investigation of the role of the Bundestag and, in particular, of the Federal Ministry of Finance in the proceedings concerning the Hypo Real Estate (Hypo-RealEstate IC)," Bundestag print 16/14000 (18 September 2009), 35: "Sequence of Hearings."

48 It sometimes happens that the members of the coalition and those of the opposition cannot agree on when to summon a certain witness. Usually, the summons is done according to the so-called zipper procedure: both sides make suggestions on who to hear, until the matter culminates in the hearing of a minister. There are other methods, too, such as calling a number of witnesses corresponding to the size of the faction or at a ratio of one for the coalition, one for the opposition.

49 As a rule, only a limited number of visitors are interested in the proceedings. Media representatives, however, are usually present at the sessions when the hearing of witnesses promises to be interesting. Audio and video recordings are prohibited. They are, however, permitted right before a session, which usually results in pictures of ministers or high officials taking the witness stand.

50 According to $\S 14$ of the Committees of Inquiry Act, the public is excluded if personal issues of witnesses or third parties come up, and if the public discussion of these issues would harm interests worth protecting; endanger the life, health, or freedom of the individual witness or another person; or if the discussion of a business, trade, invention, or tax secret that is likely to be mentioned would harm interests worth protecting or would be detrimental to the federation or a state, particularly if the security of the federal republic or its relations to other states are concerned. 
matter to be discussed. An ordinary resolution of the committee members is sufficient to bring this decision about. According to Section 12, Para. 3 of the COI Act, the statements made in closed hearings may not be made public by individual committee members; only the committee as a whole may make information public. ${ }^{51}$ Yet sometimes in the wake of a meeting individual deputies will brief the media on the hearings. However, it is possible to protect classified materials and guarantee document security according to Sections 15 and 16 of the COI Act and to achieve the appropriate classification. Taking evidence that is classified as confidential or higher must then take place in another, secure, room. ${ }^{52}$

Sometimes a request is made that witness testimony and the COI's minutes be declassified so that statements can be entered into the record of the public hearings of witnesses. ${ }^{53}$ It can also facilitate the discussion in the media regarding past misconduct. So far, the government has always complied after considering the parliamentary requests. As a consequence, the security agencies had to check all classified minutes and ensure that, after the redaction of sensitive passages, they were fit for publication. This often involves hundreds of pages and multiple departments. Thus, the coordination of proposals among the different security agencies as to which passages are to be redacted can be tedious.

As was explained above, the witness may refer to the limited scope of the permission to give evidence as a reason for declining to answer a question. The witness may also refuse to answer any questions of a speculative or hypothetical nature, and may adhere to his or her own observations and direct knowledge. ${ }^{54}$ The COI members may, however, ask the witness about his or her assessment of events or persons, even if such assessment is abstract. If the witness does not wish to testify on a concrete question in front of the committee, or believes that the limits of the right to take evidence have been reached,

51 Each member of the committee is free to inform the public about the consultations and the decision making in a session of evidence gathering which is "only" categorized as non-public. For the effective protection of secrets and classified materials that come from the domain of the government and are to be made public during a hearing of witnesses, additional protection is required. This type of physical and procedural protection is guaranteed by $\S 15$ and $\S 16$ of the Committees of Inquiry Act after the appropriate classification has been made.

52 See $\S 14$ of the Committees of Inquiry Act and $\S 9$ of the Committees of Inquiry Act of the Berlin Chamber of Deputies.

53 The COI decides whether witness testimonies are classified; see $\S 15$, Paras. 1 and 2 , in conjunction with $\S 14$, Para. 3 of the Committees of Inquiry Act. The decision is usually based on the classification level of the relevant material. Documents published by the COI are solely subject to the Bundestag bylaws. Whether the minutes of hearings get declassified is first of all for the COI to decide. In such cases, the government has to make sure to get involved.

54 The obligation to testify applies exclusively to facts, not to assessments, conclusions, legal issues, general impressions, assumptions, experience, etc. Questions relating to anything other than facts may get rejected as non-admissible. 
the federal government's coordinator might be obliged to supply substantive justification for this. ${ }^{55}$

\section{Leaks}

Online, television, and print media closely follow the events surrounding the committee sessions. Why the security sector finds itself in the crosshairs of parliamentary inquiries again and again is a matter of speculation. Events featuring secret agents, war, undercover operations, the CIA, the hunt for terrorists, etc. appear to still hold a certain appeal for the media. This is comprehensible from the public's point of view, as these topics obviously guarantee a kind of drama that dry and complex processes of the financial and economic sectors will never be able to generate. ${ }^{56}$ Besides that, they offer journalists plenty of opportunity to look into the questions of "who knew what and when did they know it" regarding political decision makers. Ultimately, this is another facet of both the public and the parliament's desire to inquire into cases of misconduct, corruption, and misappropriation of funds. 57

During the last few COIs that dealt with issues concerning foreign and security policy, there were several publications in the press referring to documents that had been sent to the committee's secretariat only shortly before. ${ }^{58}$ These documents were of all classification levels. How the few available copies of these documents came into the possession of the journalists was never established. In this context, the Bundestag declared that the access to classified documents, the circle of authorized persons, and the safe-keeping within the Secret Records Office is sufficiently regulated by the COI. ${ }^{59}$

Because the contents of the documents immediately became public, they could be easily quoted during the committee sessions. The government kept insisting that publication does not change the classification level, though this call often went unheeded in the public debate. ${ }^{60}$ Witnesses were sometimes put in an awkward position. Quite often, they were confronted with newspaper articles publicly quoting classified documents

55 When testifying before a COI, witnesses do not have to say anything that can be used against them. However, according to $\S 22$ of the COI Act, the reasons for their refusal must be clarified. Therefore, facts and credibility are required - mere statements are not sufficient. See Decisions by the Federal Constitutional Court 124, 78 [131f.].

56 See, for example, "Hypo Real Estate Committee"; "The Process of an Inquiry," $26 \mathrm{ff}$.

57 Hans Born, "Towards Effective Democratic Oversight of Intelligence Services: Lessons Learned from Comparing National Practices, Connections 3:4 (2004): 11.

58 See "First COI of the Sixteenth EP," $51 \mathrm{ff}$; "The Dilemma of Non-Disclosure."

59 See "First COI of the Sixteenth EP," $51 \mathrm{ff}$ : "Since it turned out to be impossible to guarantee effective protection of the documents made available by the federal government in spite of collective efforts, the head of the chancellery announced that the federal government intended to hand over material classified as confidential or with a higher classification level only on condition that the material be accessed exclusively at the Document Security Office of the German Bundestag."

${ }^{60}$ See $\S 9$, Para. 1, Administrative Regulation of Classified Documents; § 3, Para. 2, Rules of Procedure of the Bundestag. 
while the classification grade of the original information had not changed. Consequently, the authorities took into consideration that every classified document that is to be brought before the COI might become known to the press as well. Documents that were classified "confidential" or higher were henceforth exclusively sent to the Bundestag's Secret Records Office. This illustrates that on the one hand the leaks advanced the public debate to the disadvantage of the authorities' security interests, but that on the other hand the authorities reacted to these new circumstances by applying a more prudent process of submitting files and by taking administrative measures that at least slowed down the accessibility of sensitive documents.

Irrespective of the Bundestag Rules of Procedure, the question remains whether this kind of indiscretion falls within the purview of and is punishable under criminal law. The relevant legal regulations can be found in the German Criminal Code in Section 203, Para. 2 and Section 353 (b), Paras. 1 and 2. Where the employees of the security agencies as office-holders are concerned, unauthorized copying and distribution of documents constitutes a criminal offense. The situation is different for members of parliament and their staff. In any case, the President of the Bundestag would have to authorize the prosecution.

Prosecuting a journalist who accepted information from an office-holder is even more difficult. The point is that the primary offense - the disclosure of secret information - can only be committed by a person with access to classified information. It is a matter of dispute if a journalist can be accused of "successive aiding and abetting." No matter what, the journalist is under no obligation to name the source. Since the so-called "Cicero verdict" in February 2007, the source is protected under Article 5 of the Basic Law (which guarantees freedom of the press). ${ }^{61}$

So far, all of the lawsuits that have been filed were dismissed by the various prosecutors' offices. An outraged response from the executive branch would probably be met with incredulity by the public and media: illegal or inappropriate actions have been exposed, so how can the authorities possibly now investigate parliamentarians or journalists?

${ }^{61}$ In its verdict (Decisions by the Federal Constitutional Court 117, 244 [265 f.]), the Constitutional Court specified that the mere publication of an official secret by a journalist is not sufficient cause to justify a suspicion leading to search and seizure. Instead, specific facts are required, indicating that a person in a sensitive position was actually planning to publish the secret, which would then count as an offense susceptible to complicity. See "Draft Law on the Protection of the Freedom of the Press," Bundestag print 16/4539, 6 March 2007. See also "Criticizing Investigations Against Journalists," Stern.de (3 August 2007); available at www.stern.de/politik/deutschland/bnd-untersuchungsausschuss-kritik-an-ermittlungen-gegenjournalisten-594417.html. See also "Investigations Against Journalists for Breach of Secrecy," faz.net (2 August 2007); available at www.faz.net/aktuell/politik/inland/medien-ermittlungengegen-journalisten-wegen-geheimnisverrats-1459900.html. 


\section{Discontinuation of COIs}

COIs are subject to discontinuation. This means that the investigation is terminated at the end of a legislative term, regardless of whether or not all the facts have been established or a final report has been completed. ${ }^{62}$ A COI itself may encompass thousands of pages. It consists of four parts: procedures, fact-finding issues, assessments, and appendices. The secretariat submits the first draft to the parliamentary parties for comments. No official participation of the federal government is foreseen.

After adoption by the Bundestag, the report will be published. For security agencies, this means that ambiguous text passages that were not redacted prior to publication will be accessible to the public. It is possible that classified information will not be excluded from the draft. For reasons of transparency it is common procedure that many items of information are declassified before publication in accordance with Paragraph 33 of the COI Act. The Bundestag and the federal government endeavor to prevent the inadvertent release of classified material. Thus, classified documents are not referred to as such in the final report. Instead, the report indicates press releases that describe the indiscretions.

The parliamentary factions may provide commentary on the final report. Such statements sometimes run as long as several hundred pages. ${ }^{63}$ Although issuing dissenting opinions is somewhat foreign to the German legal tradition, and is a recent borrowing from Anglo-Saxon legal practice, parliamentary statements seem to have become an established inquiry procedure. The factions may differ in their assessments, and sometimes even in their descriptions of facts and circumstances. As previously mentioned, there are no provisions for the executive branch to play a role in the production of or comment on a COI report.

Formally, a COI ends with the adoption of the final report by the Bundestag. ${ }^{64}$ The chairman of the committee submits a copy to the President of the Bundestag. This may happen simultaneously to the presentation of the report to the press. The focus of public perception is not so much on the final report itself. Due to its sheer volume, it may not be read by a wide audience anyway. The report is perhaps primarily of interest to legal experts, humanities scholars, or future historians.

These procedures round out the work of the committee in the eyes of the public. Precarious issues are recalled, accusations are repeated or refuted, and emotional moments or situations are relived. For security and law enforcement agencies, COIs often mean

62 See Rules of Procedure of the Bundestag, § 125; Wulf Damkowski, Der parlamentarische Untersuchungsausschuss: Ein Handbuch für Wissenschaft und Praxis [The Parliamentary Investigation Committee: A Manual For Academics and Practitioners] (Frankfurt: Campus Verlag, 1987), $31 \mathrm{ff}$.

63 See "Kunduz-CoI,"; "Statements," $413 \mathrm{ff}$.

64 This usually happens during the last session of the Bundestag before the summer break- that is, approximately three years before the next elections. See, for example, "First COI of the Sixteenth EP," 18 June 2009; "Plutonium COI," 28 May 1998; "Commercial Coordination," 27 May1994; "Visa COI," 2 September 2005. 
that lessons will be drawn that may lead to new guidance in order to remedy shortcomings. For instance, some administrative procedures that seemed uncomplicated and straightforward in the 1980s and 1990s have been tightened considerably as a reaction to parliamentary COIs.

\section{Serving as a Model?}

The preceding analysis has demonstrated that there is tension between legislative requirements for transparency and executive constraints on providing information. This contentious situation exists at all levels - from trivial fact-finding to sophisticated legal interpretation by the Federal Constitutional Court. In June 2009, the Federal Constitutional Court weighed the "as much as possible" call for transparency against the "as much as necessary" call for the protection of information. In the end, priority was given to transparency over security concerns.

Reform-minded groups in states making the transition to democracy might perceive this decision as an encouragement to call for more transparency from their security sector as well. From an outsider's perspective, the depth of inquiry, the time and personnel involved, as well as the interrelated legal and political aspects might seem vastly complex. The German inquiry system, with its passion for detail, fits the Teutonic stereotype. However, the constant questioning and correcting of the work of the security agencies was fundamental in postwar Germany. Germany's parliamentary inquiry system is the result of a history that other states do not necessarily have to face with such intensity.

The legal complexity is understandable considering the requests bearing on foreign and security policy from various government and opposition party coalitions that the Federal Constitutional Court has had to deal with over time. In Germany, noncompliance with a Federal Constitutional Court decision is inconceivable. Therefore, the legislative and the executive branches are making efforts to integrate Federal Constitutional Court decisions into their administrative procedures.

It needs to be stated that a COI is not only a forum for discussing opposing legal opinions and interests. In Germany, it is also a forum for discussing fundamental political issues such as the fight against global terrorism, the out-of-area deployments of German soldiers, and Germany's position within alliances.

In transition and post-conflict states, one issue might be perceived with some skepticism: the disclosure of classified information. Sometimes operative details are published - information that in most states would be kept classified. Such transparency would probably not be supported in states where the intelligence services served as pillars of power over many decades. In SSR dialogues, foreign experts usually say that transparency is desired, but not to the extent that has been realized in a Central European context. Many states that are in the process of reforming their security sectors are often still struggling with unresolved internal and external conflicts. It is often emphasized that difficult security situations are not beneficial to transparent security agencies. In other words, the fragile security environment does not permit constant justification for actions taken by the security sector. 
Transparency of security agencies is seen as something that economically prosperous states embedded in the geostrategic safety zone of the European Union can afford. Such statements need to be taken very seriously in discussions on SSR. Disentangling security structures from those of the legislative, executive, and judicial branches can be difficult, but it is important in order to find the proper checks and balances. Any serious efforts in this respect need to be honored. Reform initiatives need to take into account that each conflict presents its own conditions: conflicts in the Southern Caucasus are unresolved, conflict rhetoric in the Balkans is prevalent, and the Middle East has its own transitional dynamics. Well-meaning advice from a secure distance might be perceived by representatives of the executive branch and open-minded reformers as Western or Eurocentric arrogance.

At minimum, it is suggested that SSR projects in their beginning stages concentrate on establishing a functioning ministerial control system. Establishing permanent control organs with access to data may come next. Establishing parliamentary COIs comparable to German standards would eventually round out the reform process.

Independent of which forms of control and oversight over security agencies (including intelligence agencies) are established, it must be understood that parliamentary oversight entails a complex and detail-oriented inquiry system. It might serve as a matrix for identifying areas that are potentially deficient. In following this path, the executive and legislative branches will have to balance, permanently and in a multifaceted way, transparency and state protection. It might be convincing that, in the parliamentary control system, the executive branch has legal means and possibilities to avoid unnecessary disclosures. Committees should be seen as an opportunity to react to and correct the reasons for public criticism and to reveal controversial decision-making processes. If this approach leads to deficiencies in the security sector being identified and used to instigate institutional and personnel changes, then it should be considered a progressive step in Security Sector Reform and accordingly, Good Governance. 


\section{Bibliography}

Achterberg/Schulte Kommentar zum Grundgesetz [Commentary on the German Basic Law]. 4th ed. Vol. 2. Munich: Vahlen, 2000.

Administrative Regulation of Classified Documents., 2013.

Assessment Report of the Parliamentary Committee of Inquiry: Elbe Philharmonic Hall, Citizens of the Free and Hanseatic City of Hamburg., 2011.

BND-Ausschuss. Die Zeit online, 2006.

Born, Hans. "Towards Effective Democratic Oversight of Intelligence Services: Lessons Learned from Comparing National Practices." Connections: The Quarterly Journal 3, no. 4 (2004): 1-12.

Committee Finds that Chaos Reigns in the Security Services., 2013.

Committees of Inquiry Act of the Berlin Chamber of Deputies., 2013.

Committees of Inquiry Act., 2013.

Constitutional Court of Saxony., 2008.

Criticizing Investigations Against Journalists. Stern.de, 2007.

Damkowski, Wulf. Der parlamentarische Untersuchungsausschuss: Ein Handbuch für Wissenschaft und Praxis [The Parliamentary Investigation Committee: A Manual For Academics and Practitioners]. Frankfurt: Campus Verlag, 1987.

Decision by the 2nd COI (Visa CoI) In Bundestag print., 2005.

Decisions by the Bavarian Constitutional Court ., 2013.

Decisions by the Federal Constitutional Court., 2013.

Die parlamentarische Kontrolle der Nachrichtendienste [Parliamentary Control of the Intelligence Services]. Neue Zeitschrift für Verwaltungsrecht, 2000.

Draft Law on the Protection of the Freedom of the Press In Bundestag print., 2007.

First COI of the Sixteenth Election Period In Bundestag print., 2009.

Hecker, Jan. Anmerkung zum BVerfG-Beschluss vom 17.06.2009 [Comment on the Decision of the Federal Constitutional Court of 17 June 2009] In Deutsches Verwaltungsblatt. Vol. 19., 2009.

Hömig, Dieter. Grundgesetz für die Bundesrepublik Deutschland-Taschenkommentar. 7 th ed., 2013. 
Investigation of the role of the Bundestag and, in particular, of the Federal Ministry of Finance in the proceedings concerning the Hypo Real Estate (Hypo-Real-Estate IC) In Bundestag print., 2009.

Investigations Against Journalists for Breach of Secrecy. faz.net, 2007.

Kunduz COI In Bundestag print., 2011.

Plutonium COI In Bundestag print., 2008.

Priest, Dana. "CIA Holds Terror Suspects in Secret Prisons." Washington Post (2005).

Recommended Decision and Report of the Committee for Transport, Construction and Urban Development. Stuttgart: BT-D print, 2011.

Reinhard Bergmann in Grundgesetz für die Bundesrepublik DeutschlandTaschenkommentar [Basic Law for the Federal Republic of Germany-Pocket Commentary]. 7th ed. Berlin: Nomos, 2003.

Reply by the Federal Government: Procurement of weapons from the East by the Federal Intelligence Service and transit shipment to friendly states In Bundestag print.

Request for Setting up a COI In Bundestag print., 2012.

Request to Set up a Committee of Inquiry In Bundestag print., 2012.

Rules of Procedure of the Bundestag., 2013.

Schreiner, Hermann. "Die Berliner Stunde-Funktionsweise und Erfahrungen: Zur Redeordnung des Deutschen Bundestages [The Berlin Hour-How it works: The Rules for Speakers in the German Bundestag]." Zeitschrift für Parlamentsfragen 36, no. 6 (2005): 573-88.

The Green Party, the Liberals and the Left Party Decide to Set up a COI to Inquire into the BND Scandal. Der Spiegel online, 2006.

van Burren, Jelle. Secret Truth: The EU Joint Situation Centre. Amsterdam: Eurowatch, 2009.

Visa COI In Bundestag print., 2005.

We Literally Know Nothing. Süddeutsche Zeitung, 2012. 